\title{
Effects of Leaf Extracts of Selected Plants on Quality of Stored Citrus sinensis (Sweet Orange) Juice
}

\author{
Oluwagbenga O. ADEOGUN*, Adedotun A. ADEKUNLE, \\ Erute M. ADONGBEDE
}

\author{
University of Lagos Akoka, Faculty of Science, Department of Botany, Lagos state, \\ Nigeria; adeogunoluwagbenga@gmail.com (*correspondingauthor); aaded63@yahoo.com; erute70@yahoo.com
}

\begin{abstract}
Reduction in the quality of fruits during storage has been a concern to the consumers and the effect can be felt on the economy of developing countries. Leaves of plants such as Canna indica, Megaphrynium macrostachyum and Thaumatococcus daniellii have been documented as food packaging materials in West Africa. Based on this, the quality of stored sweet orange juice was investigated using ethanolic extracts of leaves of $C$. indica, M. macrostachyum and $T$. daniellii to enhance the shelf life of the juice. The extracts were used to assess the quality of juice for 30 days using quantitative parameters such as total soluble solid, browning potential, $\mathrm{pH}$, microbial analysis and turbidity at $4{ }^{\circ} \mathrm{C}$ and at room temperature $\left(27-31^{\circ} \mathrm{C}\right)$. The qualitative and quantitative phytochemical constituents of the extracts were determined. The extracts' toxicity was determined using Brine shrimp. The quality assessment evidently revealed that the freshly squeezed orange juice with the extracts possess tolerable activity to enhance the shelf life of orange juice. The leaf extract of $M$. macrostachyum had the highest preservation rate on the juice after 30 days. The qualitative phytochemical screening revealed the presence of alkaloid, tannin, saponins, flavonoids, steroids and terpenoids in the three plants tested. The quantitative phytochemical analysis of the most active extracts in the three plants revealed that $M$. macrostachum had the highest contents of alkaloids $(107.48 \mathrm{mg} / \mathrm{g})$ and flavonoids $(56.92 \mathrm{mg} / \mathrm{g})$.The study showed that the extracts were non-lethal on Brine shrimp. This study ascertained the potential preservative qualities of the test plants for enhancing the shelf-life of orange juice.
\end{abstract}

Keywords: leaf, orange juice, plant extracts, quality, shelf life

\section{Introduction}

Citrus sinensis is a member of the Citrus family, along with mandarins (tangerines), lemons, limes and grapefruit (Etebu and Nwauzoma, 2014). The fruit of Citrus sinensis forms a significant part of human diet and is usually regarded as a good source of food (Etebu and Nwauzoma, 2014). The fruits, which are the succulent part of Citrus sinensis are characterized by a sweet or acid taste and distinct flavour. The juice, which is directly extracted from the fruits of $C$. sinensis is of high nutritional value and of significant contribution to the health of humans (Bevilacqua et al., 2011).

Food products which are perishable, once introduced into the market, requires protection against spoilage during storage and distribution (Bhat et al., 2012). The longevity and extension of the shelf life of food involves the need to make it to be stable and safe for consumption through preservation (Brul and Coote, 1999; Adegunloye et al., 2006).

The reduction in quality of food might be ascribed to the activities of microorganisms. Preservation is a process by which enhancing agents are used to keep food from deteriorating. This enables the food to retain freshness, texture, colour, nutritional value and flavour (Gould, 1999).

Microbial spoilage of food decreases the shelf life of the food, which may result in substantial economic losses and potential health hazards to the consumers (Grillo and Lawal, 2010).

During production of food, it is crucial that proper measures are taken to ensure safety and stability of the product during its whole shelf-life (Brul and Coote, 1999). Food preservation is becoming an increasing issue to the survival and well-being of humans. The essence of preservation, which can be attached to food safety, is evidenced by the consumer preference for naturally 
occurring preservatives and this arose due to the toxicological problems that have prevailed due to the use of synthesized preservatives and additives.

The need for food products that are free from contamination and toxicological problem is driving a trend towards natural preservatives (Gould, 1999; Brul and Coote, 1999; Adegunloye et al., 2006; Dolf De Rovira, 2008; Bhat et al., 2012; Adeogun et al., 2016). Traditionally, many natural substances, such as sugar, salt, vinegar and alcohol have been used as natural preservatives. Many herbs and spices have also been screened for antimicrobial activity, but only few have been exploited as food preservatives on a commercial basis (Adekunle, 2000a; Adekunle, 2000b; Ogbulie et al., 2007; Tiwari et al., 2009; El-Mahmood, 2010).

The use of leaves to preserve food in Nigeria is quite popular and acceptable. It uses cut across the teeming populace in every geographical part of the country. Depending on location and locality, various types of plant leaves are used as wrappers, e.g. Musa sapentium, Musa paradisiaca, Cola nitida, Cola acuminata, Piliostigma reticulatum, Theobromae cacao, Colocasia esculenta, Canna indica, Megaphrynium macrostachyum and Thaumatococcus daniellii leaves (Adegunloye et al., 2006), to package and present foods to clientele. The use of these leaves is ancient in various ways depending on the traditions of population; thus its basis cannot be easily ascertained, but a cursory look at these leaves reveal that they all have large surface areas, thus they can be used to hold/package/wrap large volumes of food (Ojekale et al., 2007).

Thaumatococcus daniellii (Benn.) Benth. belongs to family Marantaceae; it grows throughout the hot, humid tropical rain forest and coastal zone of West Africa. Its natural habitat is the undergrowth of forest trees. Large quantities of its fruit are consumed by the local people to sweeten over fermented palm wine and sour foods. From the aril of $T$. danielliii, an intensely sweet, non-toxic and heat stable protein - thaumatin - is extracted. This is used as sweetener or taste modifier in beverages, desserts, chewing gums and pet foods (Onwueme et al., 1979).

Megaphrynium macrostachyum (Benth.) Milne-Redh belongs to family Marantaceae. The leaf is papery and is much used as a roof-thatch. The leaf-petiole is often split and dyed for mat making in Nigeria (Milne-Redhead, 1952).

Canna indica Linn. belongs to the family Cannaceae. They are widely spread in tropical Africa, chiefly in the forest zone, near villages and along the roads. They are herbaceous plants, rhizomatous, forming small to large monotypic stands and the leaves are green. The leaves are used for wrapping food. The seed are made into necklaces and rosaries; children use them as shot in pop-guns (Dalziel, 1937).

The objective of the current study was to analyse the effect of ethanol extracts from leaves of Canna indica, Megaphrynium macrostachyum and Thaumatococcus daniellii on quality of stored Citrus sinensis (sweet orange) juice.

\section{Materials and Methods}

\section{Collection of the plant leaves}

The leaves of Canna indica, Megaphrynium macrostachyum and Thaumatococcus daniellli were collected from the Botanical Garden, University of Lagos. The plants were authenticated at Lagos University Herbarium.

\section{Milling ofplant samples}

The leaves of $C$. indica, $M$. macrostachyum and $T$. daniellii were shade-dried for ten days and ground using a specialized grinding machine at the Department of Pharmacognosy, Faculty of Pharmacy, University of Lagos.

\section{Extraction of plant extracts}

Two hundred grams of ground leaves of $C$. indica, $M$. macrostachyum and $T$. daniellii were weighed differently and soaked with $400 \mathrm{ml}$ of ethanol in different conical flasks. These were corked with adsorbent wool wrapped with aluminium foil and shook on Labcon Platform shaker (Laboratory Consumables, PTY, Durban, South Africa) for 72 hrs. The extracts were filtered into sterilized conical flasks using Whatman No. 1 filter paper. The filtrates were concentrated under reduced pressure $40{ }^{\circ} \mathrm{C}$ using rotary evaporator (Cole Parmer SB 1100, Shangai, China). The solvent used was of high analytical grade (Merck Chemicals (PTY), Wadeville, South Africa).

\section{Comparative study of the shelf-life of treated and untreated orangejuice}

The juice was prepared at room temperature in the ultra-violet room of the postgraduate research laboratory of Department of Botany, University of Lagos. Two millilitres of reconstituted extracts (C. indica, $M$. macrostachyum and T. daniellii) with Dimethyl sulfoxide (DMSO) was added to the prepared juice in a tube with lid. This was carried out in an aseptic condition to curtail the growth of contaminants that can accelerate spoilage. Preservative $(1.25$ $\mathrm{mg} / \mathrm{ml}$ ascorbic acid) were added to another set of prepared juice. The juice alone was also prepared along with branded juice. These were aseptically and quickly opened and poured into tube with lids, all tubes were assessed via the following parametres: $\mathrm{pH}$, total soluble solid, browning potential, turbidity, visual assessment and microbial load count using Martin-Diana et al. (2009) and Gil et al. (2006) as guide. The tubes were stored for 30 days at $4{ }^{\circ} \mathrm{C}$ and room temperature $\left(27-31^{\circ} \mathrm{C}\right.$ ); assessed at intervals (day $0,7,14$ and 30). The samples for analyses were prepared in triplicates.

\section{pHanalysis}

The $\mathrm{pH}$ of $20 \mathrm{~mL}$ orange juice was determined at room temperature and constant agitation using a $\mathrm{pH}$-meter (model 420A, Orion, USA). It was expressed as the negative logarithm of the hydrogen ion concentration in a solution.

\section{Total soluble solids 'TSS' ( ${ }^{\circ}$ Brix)}

The Brix was determined by measurement of the refraction index with a refractometer (Bellingham and Stanley, England) at room temperature. Refractive index 
258

was recorded and expressed as ${ }^{\circ}$ Brix. Measurements were performed at room temperature.

\section{Browningpotential}

Ten millilitres of fresh orange juice were treated with ethanol for $60 \mathrm{~min}$ and then centrifuged at 4,830 $\times \mathrm{g}$ at $10{ }^{\circ} \mathrm{C}$ for $10 \mathrm{~min}$, retaining the supernatants. After, a further amount of ethanol was added to bring the final volume to $25 \mathrm{~mL}$. Absorbance at $320 \mathrm{~nm}$ of aliquots of these extracts was measured. The results were expressed as absorbance units $(\mathrm{AU}) \mathrm{mL}^{-1}$ fresh orange juice.

\section{Turbidity}

The turbidity of each sample of juice was measured using a direct reading spectrophotometer (model DR/2000, Hach, USA). The wavelength of the instrument was brought to $810 \mathrm{~nm}$ and deionised water used as a blank. The measurements of the samples of orange juice were done in triplicate with a solution of $1: 25$ (juice/water), to work within the detectable range. The results were given in milligrams of suspended solids per litre of solution.

\section{Microbial load counting}

Microbial analyses were carried out on the samples at regular intervals through the storage period. One millilitre of decimal dilution of orange juice samples was pipetted to petri dishes $(25 \mathrm{ml}$ of fresh orange juice was homogenised in $225 \mathrm{ml}$ of $0.1 \%(\mathrm{w} / \mathrm{v})$ sterile peptone water with a homogenizer). The total number of viable cells in the suspension was calculated by the methylene blue method of Lee et al. (1981) using a hemocytometre. A drop of the suspension was placed on the ruled area of a clean Neubauer counting chamber. A cover slip was placed first and the cells were permitted to run underneath by capillary action from Pasteur pipette tip. The counting cell was allowed to stand for 10 min to permit the viable cells to settle into the same focal plane as much as possible. Using a light microscope, the fungal spores were counted with $10 x$ ocular and $5 \mathrm{~mm}$ objective and this was done for the total grid in triplicate. The cell count was calculated thus:

Viable cells $/ \mathrm{ml}=$ Number of cells in total grid $\times$ dilution factor $\times 10^{-4}$.

\section{Cytotoxicity test using brine shrimp}

The brine shrimps cytotoxicity test using the larvae of brine shrimp nauplii, Artemia salina L., was carried out using the method adopted by Adeogun et al. (2016). $1 \mathrm{mg}$ $\mathrm{ml}^{-1}$ concentration of reconstituted extracts was prepared from the original stock solution of $C$. indica, $M$. macrostachyum and $T$. daniellii that was used for comparative shelf life study. The oils were further diluted to final concentrations of 20, 40, 60, 80 and $100 \mathrm{ugml}^{-1}$ in different vials using DMSO. Ten nauplii were transferred into each vial using Pasteur pipettes and were not given food because hatched brine shrimp can survive up to 48 hours without food, as they still feed on their yolk during this period. The control vials contained normal saline solution and dimethyl sulfoxide (DMSO) separately. The experiments were done in triplicate. After 24 hours of incubation, the content of each vial was transferred into 65 $\mathrm{mm}$ Petri dish and examined; the number of surviving larvae was counted and the percentage of mortality was evaluated. Larvae were considered dead if they did not exhibit any form of movement during several seconds of observation. Extracts are regarded as non-toxic if its LC50 is greater than $100 \mathrm{\mu g} \mathrm{ml}^{-1}$ in brine shrimp lethality assay.

\section{Qualitative and quantitative phytochemical screening}

Ethanol extracts of C. indica, M. macrostachyum and $T$. daniellii were subjected to qualitative preliminary phytochemical screening and quantitative analysis of the phytochemical constituents by adopting the methods described by Adeogun et al. (2016).

\section{Statistical analysis}

The data obtained from $\mathrm{pH}$, total soluble solid, browning potential, turbidity and microbial load count analysis were analysed using SPSS 20.0 (Leech et al., 2008).

\section{Results}

\section{Authenticated plant samples}

The accession numbers of deposited test plant leaves are LUH 6087, 6088 and 6089 for T. danielli, $M$. macrostachyum and C. indica respectively.

\section{Comparative study of the shelf-life}

The effects of the parameters of orange juice prepared with extracts of $T$. daniellii, $C$. indica and $M$. macrostachyum in separate tubes, prepared juice with preservative (ascorbic acid), prepared orange juice only and branded juice on days of storage and temperature ranges $\left(4{ }^{\circ} \mathrm{C}\right.$ and $\left.27-31{ }^{\circ} \mathrm{C}\right)$ are depicted in Table 1 . The results showed that there was variation in values as the day of storage increased from day 0 to day 30 taking into cognizance the temperature used to store the samples. The $\mathrm{pH}$ values of the juice stored at $4{ }^{\circ} \mathrm{C}$ with $T$. daniellii were $4.25 \pm 0.003$ at day 0 and $4.44 \pm 0.003$ at day 30 , while the $\mathrm{pH}$ values at room temperature were $4.65 \pm 0.018$ at day 0 , while $4.75 \pm 0.013$ for day 30 . The values of browning potential of the juice stored at $4{ }^{\circ} \mathrm{C}$ with $C$. indica leaf extract were $0.98 \pm 0.003$ at day 0 and $1.65 \pm 0.02$ at day 30 , while the browning potential values at room temperature were $1.22 \pm 0.001$ at day 0 , while $1.43 \pm 0.002$ for day 30 . The values of the turbidity state of stored juice with $M$. macrostachyum at $4{ }^{\circ} \mathrm{C}$ were $0.28 \pm 0.003$ at day 0 and 0.24 \pm 0.002 at day 30 , while the turbidity values at room temperature were $0.36 \pm 0.100$ at day 0 and $0.24 \pm 0.002$ for day 30 .

\section{Qualitative phytochemical screening and quantitative analysis determination}

The qualitative phytochemical constituents of $C$. indica, $M$. macrostachyum and T. daniellii leaf extracts are shown in Table $2 \mathrm{a}$ signified the presence of alkaloids in $\mathrm{M}$. macrostachyum and T. daniellii, tannins in C. indica and T. daniellii and saponins in the 3 extracts.

The results of the quantitative phytochemical constituents of extracts of C. indica, M. macrostachyum and T. daniellii leaves is depicted in Table $2 \mathrm{~b}$. 
Table 1. Quality parameters of stored fresh orange juice for 30 days

\begin{tabular}{|c|c|c|c|c|c|c|c|c|c|}
\hline \multirow{2}{*}{$\begin{array}{l}\text { Juice } \\
\text { Type }\end{array}$} & \multirow{2}{*}{ Day } & \multicolumn{2}{|c|}{$\mathrm{pH}$} & \multicolumn{2}{|c|}{ Browning Potential } & \multicolumn{2}{|c|}{ Turbidity } & \multicolumn{2}{|c|}{ Total Soluble Solid } \\
\hline & & $4^{\circ} \mathrm{C}$ & RT $\left(27-31^{\circ} \mathrm{C}\right)$ & $4^{\circ} \mathrm{C}$ & RT $\left(27-31^{\circ} \mathrm{C}\right)$ & $4^{\circ} \mathrm{C}$ & RT $\left(27-31^{\circ} \mathrm{C}\right)$ & $4{ }^{\circ} \mathrm{C}$ & $\operatorname{RT}\left(27-31^{\circ} \mathrm{C}\right)$ \\
\hline \multirow{4}{*}{$\begin{array}{c}\text { TDL + } \\
\text { Juice }\end{array}$} & Day 0 & $4.25 \pm 0.003$ & $4.65 \pm 0.018$ & $1.32 \pm 0.003$ & $1.62 \pm 0.019$ & $0.29 \pm 0.002$ & $0.30 \pm 0.027$ & 10.100 & 10.100 \\
\hline & Day 7 & $4.28 \pm 0.004$ & $4.50 \pm 0.033$ & $1.42 \pm 0.006$ & $1.74 \pm 0.005$ & $0.30 \pm 0.000$ & $0.31 \pm 0.003$ & 10.100 & 10.100 \\
\hline & Day 14 & $4.32 \pm 0.002$ & $4.77 \pm 0.028$ & $1.47 \pm 0.005$ & $1.65 \pm 0.003$ & $0.29 \pm 0.001$ & $0.34 \pm 0.003$ & 10.800 & 10.800 \\
\hline & Day 30 & $4.44 \pm 0.003$ & $4.75 \pm 0.013$ & $1.59 \pm 0.002$ & $1.64 \pm 0.001$ & $0.29 \pm 0.003$ & $0.29 \pm 0.003$ & 10.800 & 10.700 \\
\hline \multirow{4}{*}{$\begin{array}{l}\text { CIL + } \\
\text { Juice }\end{array}$} & Day 0 & $4.34 \pm 0.000$ & $4.64 \pm 0.012$ & $0.98 \pm 0.003$ & $1.65 \pm 0.02$ & $0.34 \pm 0.003$ & $0.34 \pm 0.070$ & 10.100 & 10.100 \\
\hline & Day 7 & $4.39 \pm 0.003$ & $4.59 \pm 0.004$ & $1.11 \pm 0.002$ & $1.65 \pm 0.03$ & $0.29 \pm 0.001$ & $0.32 \pm 0.002$ & 10.100 & 10.100 \\
\hline & Day 14 & $4.29 \pm 0.12$ & $4.82 \pm 0.010$ & $1.21 \pm 0.003$ & $1.76 \pm 0.004$ & $0.36 \pm 0.000$ & $0.36 \pm 0.002$ & 10.900 & 10.700 \\
\hline & Day 30 & $4.43 \pm 0.02$ & $4.67 \pm 0.02$ & $1.22 \pm 0.001$ & $1.43 \pm 0.002$ & $0.35 \pm 0.002$ & $0.35 \pm 0.002$ & 10.900 & 10.700 \\
\hline \multirow{4}{*}{$\begin{array}{c}\text { MML + } \\
\text { Juice }\end{array}$} & Day 0 & $4.28 \pm 0.003$ & $4.47 \pm 0.002$ & $1.06 \pm 0.003$ & $1.65 \pm 0.006$ & $0.28 \pm 0.003$ & $0.36 \pm 0.100$ & 10.100 & 10.100 \\
\hline & Day 7 & $4.31 \pm 0.003$ & $4.25 \pm 0.009$ & $1.34 \pm 0.004$ & $1.77 \pm 0.004$ & $0.21 \pm 0.002$ & $0.31 \pm 0.003$ & 10.100 & 10.100 \\
\hline & Day 14 & $4.37 \pm 0.003$ & $4.70 \pm 0.001$ & $1.48 \pm 0.004$ & $1.79 \pm 0.000$ & $0.26 \pm 0.003$ & $0.34 \pm 0.002$ & 10.800 & 10.700 \\
\hline & Day 30 & $4.44 \pm 0.002$ & $4.63 \pm 0.05$ & $1.62 \pm 0.004$ & $1.63 \pm 0.001$ & $0.24 \pm 0.002$ & $0.24 \pm 0.002$ & 10.800 & 10.700 \\
\hline \multirow{4}{*}{$\begin{array}{c}\text { Ascorbic } \\
\text { Acid }\end{array}$} & Day 0 & $4.29 \pm 0.003$ & $4.66 \pm 0.04$ & $0.77 \pm 0.003$ & $1.49 \pm 0.029$ & $0.32 \pm 0.003$ & $0.42 \pm 0.030$ & 10.100 & 10.100 \\
\hline & Day 7 & $4.33 \pm 0.003$ & $4.66 \pm 0.006$ & $0.84 \pm 0.01$ & $1.33 \pm 0.004$ & $0.38 \pm 0.003$ & $0.30 \pm 0.003$ & 10.100 & 10.100 \\
\hline & Day 14 & $4.54 \pm 0.003$ & $4.44 \pm 0.01$ & $0.84 \pm 0.003$ & $1.64 \pm 0.02$ & $0.34 \pm 0.002$ & $0.33 \pm 0.002$ & 10.060 & 10.030 \\
\hline & Day 30 & $4.72 \pm 0.004$ & $4.28 \pm 0.02$ & $1.92 \pm 0.006$ & $1.28 \pm 0.001$ & $0.37 \pm 0.003$ & $0.17 \pm 0.002$ & 10.050 & 10.030 \\
\hline \multirow{4}{*}{$\begin{array}{c}\text { Fresh } \\
\text { Orange } \\
\text { Juice }\end{array}$} & Day 0 & $4.19 \pm 0.003$ & $4.66 \pm 0.02$ & $1.18 \pm 0.003$ & $1.54 \pm 0.04$ & $0.12 \pm 0.003$ & $0.20 \pm 0.120$ & 10.050 & 10.050 \\
\hline & Day 7 & $4.29 \pm 0.003$ & $4.59 \pm 0.003$ & $1.64 \pm 0.003$ & $1.36 \pm 0.003$ & $0.22 \pm 0.003$ & $0.10 \pm 0.002$ & 10.050 & 10.040 \\
\hline & Day 14 & $4.42 \pm 0.003$ & $4.40 \pm 0.02$ & $1.69 \pm 0.001$ & $1.60 \pm 0.002$ & $0.22 \pm 0.000$ & $0.15 \pm 0.005$ & 10.020 & 10.030 \\
\hline & Day 30 & $4.67 \pm 0.002$ & $4.47 \pm 0.03$ & $1.78 \pm 0.01$ & $1.24 \pm 0.001$ & $0.34 \pm 0.002$ & $0.19 \pm 0.003$ & 9.400 & 10.000 \\
\hline \multirow{4}{*}{$\begin{array}{l}\text { Branded } \\
\text { Juice }\end{array}$} & Day 0 & $3.71 \pm 0.003$ & $0.27 \pm 0.001$ & $0.27 \pm 0.001$ & $0.95 \pm 0.10$ & $0.14 \pm 0.003$ & $0.36 \pm 0.035$ & 10.100 & 10.100 \\
\hline & Day 7 & $3.99 \pm 0.003$ & $3.71 \pm 0.02$ & $0.74 \pm 0.002$ & $0.74 \pm 0.03$ & $0.22 \pm 0.003$ & $0.24 \pm 0.003$ & 10.100 & 10.090 \\
\hline & Day 14 & $4.44 \pm 0.003$ & $3.72 \pm 0.03$ & $0.76 \pm 0.004$ & $0.68 \pm 0.004$ & $0.27 \pm 0.003$ & $0.15 \pm 0.002$ & 10.060 & 10.080 \\
\hline & Day 30 & $4.65 \pm 0.003$ & $4.53 \pm 0.03$ & $0.82 \pm 0.002$ & $0.65 \pm 0.002$ & $0.29 \pm 0.002^{\mathrm{e}}$ & $0.02 \pm 0.002^{f}$ & 10.060 & 10.070 \\
\hline
\end{tabular}

TDL: Thaumatococcus daniellii Leaf, CIL: Canna indica Leaf, MML: Megaphrynium macrostachyum Leaf

Table 2a. Qualitative phytochemical screening of leaf extracts of test plants

\begin{tabular}{ccccc}
\hline \multirow{2}{*}{ S/No. } & Phytoconstituent & & \multicolumn{2}{c}{ Leaf extract } \\
\cline { 3 - 4 } & Alkaloid & Canna indica & Megaphrynium macrostachyum & Thaumatococcus daniellii \\
\hline 1 & Tannins & - & + & - \\
+ & - & + \\
3 & Phlobatannins & + & + \\
4 & Saponins & - & - & + \\
6 & Flavonoids & - & - \\
7 & Steroids & - & - \\
8 & Terpenoids & - & - \\
\hline
\end{tabular}

Table 2b. Quantitative phytochemical determination of leaf extracts of test plants

\begin{tabular}{|c|c|c|c|c|}
\hline \multirow{2}{*}{ Leaf extract } & \multicolumn{4}{|c|}{ Phytoconstituents (mg/100 g) } \\
\hline & Alkaloids & Tannins & Saponins & Flavonoids \\
\hline Canna indica & - & 17.81 & 17.55 & - \\
\hline Megaphrynium macrostachyum & 107.48 & - & 7.66 & 56.92 \\
\hline Thaumatococcus daniellii & 98.96 & 81.77 & 22.92 & 35.03 \\
\hline
\end{tabular}

Table 3. Cytotoxicity assay of leaf extracts of test plants on Brine shrimp

\begin{tabular}{|c|c|c|c|c|c|c|}
\hline \multirow{2}{*}{ Conc. $(\mu \mathrm{g} / \mathrm{ml})$} & \multirow{2}{*}{ Total No. } & \multicolumn{2}{|c|}{ Control } & \multicolumn{3}{|c|}{ Ethanol extracts } \\
\hline & & DMSO & Saline water & C. indica & M. megaphrynium & T.daniellii \\
\hline 20 & 10 & 0 & 0 & 2 & 1 & 1 \\
\hline 40 & 10 & 0 & 0 & 2 & 1 & 3 \\
\hline 60 & 10 & 0 & 0 & 1 & 1 & 2 \\
\hline 80 & 10 & 0 & 0 & 3 & 3 & 2 \\
\hline 100 & 10 & 0 & 0 & 3 & 5 & 4 \\
\hline \multicolumn{4}{|c|}{$\mathrm{LC}_{50}$} & $233.03 \mu \mathrm{g} / \mathrm{ml}$ & $107.21 \mu \mathrm{g} / \mathrm{ml}$ & $281.12 \mu \mathrm{g} / \mathrm{ml}$ \\
\hline
\end{tabular}


260

Cytotoxicity activities of extracts of $C$. indica, $M$. megaphrynium and T. danielli

The lethality concentration of extracts required to kill fifty percent of population of Brine Shrimps is depicted in Table 3. It shows that the ethanol extracts of $C$. indica, $M$. megaphrynium and T. daniellii of $233 \mu \mathrm{g} / \mathrm{ml}, 107.21 \mu \mathrm{g} / \mathrm{ml}$ and $281.12 \mu \mathrm{g} / \mathrm{ml}$ respectively were not toxic because they were above general toxicity test agreement of LD50. A plant is assumed to be safe when its LD50 is above the general toxicity agreement of $100 \mu \mathrm{g} / \mathrm{ml}$.

\section{Discussion}

The increase in consumption of fruit juices has significant positive influence on third world economy and this can be affected by microbial attacks, which reduce their availability in the markets (Aneja et al., 2014). The need to enhance the shelf-life of orange juice and ward off the influence of microbes raised the need for preservation. The synthetic antimicrobial agents and chemically synthesized food preservatives have been used since antiquity as an effective method for controlling food spoilage. Nowadays, consumers concern toward chemical preservatives paves way for an increasing interest on some natural antimicrobials that can be obtained from plant extracts (Perricone et al., 2015).

The ethanol extract of individual test plant assayed for quality assessment of the orange juice at two different storage conditions: $4^{\circ} \mathrm{C}$ and $27-31^{\circ} \mathrm{C}$ showed that the juice depreciated in quality. There was disparity in the level of deterioration of the juice treated with the extracts compared with the juice without the extracts (fresh juice only, branded juice and fresh juice plus ascorbic acid). There was higher $\mathrm{pH}$ values in the juice treated with the extracts compared with the untreated juice and this can be ascribed to the addition of the extracts. The increase was for 30 days of storage. The increase in $\mathrm{pH}$ values of juice without extracts compared with the one with the extract can be ascribed to the capacity of the extracts to reduce fruit acidity based on its acid-binding properties (Cortes et al., 2008). The observation also supported by previous work by MartinDiana et al. (2009) even though the study dwelt on chitosan as agent of preservation. Abd and Niamah (2012) reported that the increase in $\mathrm{pH}$ values of orange juice treated with chitosan compared with untreated orange juice might be due to the capacity of chitosan to reduce fruit juice acidity based on its acid-binding properties. They also pointed out that when the $\mathrm{pH}$ is lower than 6.5, chitosan carries a positive charge along its backbone which implies a decrease in the buffering property of the juice. Such effect was not observed in the hereby study, as all samples showed a similar $\mathrm{pH}$ increase over storage time. The current study recorded higher values in $\mathrm{pH}$ range compared with previous works of Martin Diana et al. (2009) and Abd and Niamah (2012).

The activity of the extracts with juice compared to fresh juice only can be ascribed to the ability of the positive charged polysaccharides in the extracts to coagulate suspended solids and this increased the flocculation capacity of the extracts, which aids the binding of the negatively charged sugar (Martin-Diana et al., 2009). The Brix values of the total soluble solids of the juice observed in the current study were higher than those reported by several authors on fruit juices enhanced with natural antimicrobials (Cortes et al., 2008; Martin-Diana et al., 2009; Abd and Niamah, 2012). This might be attributed to different factors such as nutritional composition of the fruit juices, genetics, growing environment, management practises and maturity time of the fruits.

The results of the study also showed that browning potential of the juice without the addition of the extract rapidly reduced, while the browning potential of juice with individual extract had slow reduction. Higher increase of the browning potential values of fresh juice compared with the one with the extract can be attributed to enzymatic properties of the extracts and the control of browning could be associated with the capacity to coagulate solids to which browning-related enzymes are bound (Abd and Niamah, 2012; Martin-Diana et al., 2009). Martin-Diana et al. (2009) explained that browning reduction in oranges clarified with chitosan could be as a result of antioxidant capacity of chitosan which is similar to capacity associated with phenolic compounds. The similarity with phenolic compounds could explain the anti-oxidative property.

The increase in turbidity values of the juice with extract as the days of storage increased is at variance with the increase in orange juice without treatment, which had higher increase than the juice with the extract. Fresh orange juice is usually cloudy and this is an acceptable and desirable component of the juice (Sin et al., 2006). The turbidity in the juice is mainly caused by the polysaccharides present in the juice (Grassin and Fauquembergue, 1996). The increase in turbidity values of the juice with extract during storage disagree with earlier works of Abd and Niamah (2012) and Martin-Diana et al. (2009) that reported the reduction in turbidity values during storage using chitosan.

The microbial count of juice stored for a period of 30 days indicated that the extracts also delayed growth of microbes in orange juice compared to orange juice without the extracts portending a positive effect for the extension of the shelf-life. The reduction in load of microbes in juice with the extract compared with untreated juice without extract suggested an active antimicrobial effect of the extracts occurring over storage time. The mode of action of the extracts on the growth of fungi might be due to the interaction of extracts with membranes or cell wall components, the mechanism underlying the inhibition of bacterial growth is thought to be cationically charged amino-group present in the extracts which may suppress fungal growth by impairing the exchanges with the medium, chelating transition meal ions and inhibiting enzymes due to the positive charge, resulting in increased permeability of the membranes and leakage of cell material from tissue or due to water binding capacity and inhibition of various constituents within the extracts (Jung et al., 1999; Liman et al., 2011). The presence of the extract might inhibit the formation of cell wall resulting in the death of the fungi (Adekunle et al., 2005; Adekunle and Ikumapayi, 2006).

The $\mathrm{pH}$, turbidity, total soluble solids, browning potential and microbial load values of the juice when stored at $4{ }^{\circ} \mathrm{C}$ had higher delay compared to storage at room temperature $\left(27^{\circ} \mathrm{C}-31^{\circ} \mathrm{C}\right)$ which agrees with Marcilla et al. (2006) that noticed lowest off-flavour value of orange. The activity of the Megaphrynium macrostachyum extract was the highest on the parameters assayed. 
There is a general toxicity test agreement that LC50 required to kill $50 \%$ of the population of brine shrimp above $100 \mu \mathrm{g} / \mathrm{ml}$ is non-toxic, while below $100 \mu \mathrm{g} / \mathrm{ml}$ is indicative of toxicity (Adeogun $e t$ al., 2016). This study showed that the ethanol extracts from $C$. indica, $M$. macrostachyum and $T$. daniellii leaves displayed nonlethality activity against Brine shrimp nauplii with LC50 of $233.03 \mu \mathrm{g} / \mathrm{ml}, 107.21 \mu \mathrm{g} / \mathrm{ml}$ and $281.12 \mu \mathrm{g} / \mathrm{ml}$ respectively. The non-lethality of the leaf extracts of the three plants indicated that there were less harmful compounds presence in the ethanol extracts of leaves of $C$. indica, $M$. macrostachyum and $T$. daniellii. The results on cytotoxicity test on these plants validate earlier reports of Moshi et al. (2010) and Adeogun et al. (2016) and on the non-lethality of these plants. They reported that the activity of these extracts were non-lethal.

The hereby study was able to establish that the bioactive compounds present in leaf extracts of the test plants might be responsible for the enhancement of shelf life of test orange juice. The activity of the extracts showed that the test plants' leaves possess preservative properties. Qualitative phytochemical screening of the extracts revealed the presence of alkaloids, tannins, saponins and flavonoids. The quantitative phytochemical determination of the ethanol extracts of the three plants revealed high yield of tannins and saponins in C. indica, alkaloids and flavonoids in $M$. macrostachum and alkaloids, flavonoids, saponins and tannins in T. daniellii. The activity of the test plant' leaves confirmed and laid credence to several works that have identified the role of plant constituents as agents of preservation in the inhibition of food spoilage fungi (Rasooli, 2007; Corsetti and Settanmi, 2008; Efterpi et al., 2012; Lucera et al., 2012; Adeogun et al., 2016).

\section{Conclusions}

The study reported the potential of leaf extracts of $C$. indica, M. macrostachyum and $T$. daniellii as preservative agents. The in-vivo assessment of leaf extracts of the three plants on orange juice showed that they have the capability to enhance the quality of orange juice. The phytoconstituents in the extracts might be responsible for the micro-activity. There will be need to purify and elucidate the extracts to ascertain the active compounds that contribute to the enhancement of shelf life of orange juice. The current study also contribute to the drive towards the use of natural antimicrobials as preservation agents and also cement the notion that some plants are non-toxic compared to acknowledged side effects of synthetic additives.

\section{Acknowledgements}

The authors appreciate the support of the University of Lagos for granting an award of graduate fellowship, which assisted and partly contributed to the success of this research.

\section{References}

Abd AJ, Niamah AK (2012). Effect of chitosan on apple juice quality. International Journal of Research in Agriculture and Food Sciences 2(4):153-157.

Adegunloye D, Agarry O, Adebolu T, Adetuyi F (2006). Effect of leafpackaging on the microbiological assessment of some food items. African Journal of Biotechnology 5(5):445-447.

Adekunle AA (2000a). Antifungal properties of activity of Ancistrophyllum secundijlorum (Areacaceae). Journal of Phytomedicine and Therapeutics 6(1):42-48.

Adekunle AA (200b). Antifungal properties of crude extracts of Brachystelgia eurycoma (Caesalpinaceae) and Richardia brasilensis (Rubiaceae). Nigerian Journal of Natural Products and Medicine 4:70-72.

Adekunle AA, Familoni OB, Okoli SO (2005). Antifungal activity of bark extract of Ficus vallis-choudae Deelile-holl (Moraceae) and Detarium microcarpum Guill-Perr. (Caesalpinaceae). Journal of Life and Physical Sciences 2(2):64-67.

Adekunle AA, Ikumapayi AM (2006). Antifungal property and phytochemical screening of the crude extracts of Funtumia elastic and Mallotus oppositifolius. West Indian Medical Journal 55(4):219223.

Adeogun O, Adekunle A, Ashafa A (2016). Chemical composition, lethality and antifungal activities of the extracts of leaf of Thaumatococcus daniellii against foodborne fungi. Beni-Suef University Journal of Basic and Applied Sciences 5:356-368.

Aneja K, Dhiman R, Aggarwal K, Aneja A (2014). Emerging preservation techniques for controlling spoilage and pathogenic microorganisms in fruit juices. International Journal of Microbiology http://dx.doi.org/10.1155/2014/758942.

Bhat R, Alias KA, Paliyath G (2012). Progress in food preservation. Wileys and Sons Publications Limited, New Delhi.

Bevilacqua A, Corbo M, Campaniello D, D'Amato D, Gallo M, Speranza B, Sinigaglia M (2011). Shelf-life prolongation of fruit juices through essential oils and homogenization: a review. In: Mendez-Vilas A (Ed). Science against microbial pathogens: communicating current research and technological advances. Formatex Research Centre, Extramadura pp 1157-1166.

Brul S, Coote P (1999). Preservative agents in foods: mode of action and microbial resistance mechanisms. International Journal of Food Microbiology 50:1-17.

Cortes C, Esteve MJ, Frigola A (2008). Colour of orange juice treated by High Intensity Pulsed Electric Field during refrigerated storage and comparison with pasteurized juice. Food Control 19:151-159.

Dalziel JM (1937). The useful plants of tropical West Africa. Crown Overseas Agents Colonies, London.

Dolf De Rovira SR (2008). Dictionary of flavours. Blackwell Publishing ( $\left.2^{\text {nd }} \mathrm{Ed}\right)$, Iowa.

El-Mahmood MM (2010). Antibacterial potential of crude leaf extracts of Eucalyptus camaldulensis against some pathogenic fungi. African Journal of Plant Science 4(6):202-209. 
262

Etebu E, Nwauzoma A (2014). A review on sweet orange (Citrus sinensis L. Osbeck): health, diseases and management. American Journal of Research Communication 2(2):33-70.

Gould GW (2000). Preservation: past, present and future. British Medical Bulletin 56(1):84-96.

Gram L, Ravn L, Rasch M, Bruhn B, Christensen A, Givskov M (2002). Food spoilage: interactions between food spoilage bacteria. International Journal of Food Microbiology 78(1):79-97.

Grassin C, Fauquembergue P (2014). Application of pectinases in beverages. Biotechnology Progress 14:453-462.

GrilloJA, Lawal AK (2010). In-vitro activity of Thaumatococcus daniellii and Megaphrynium macrostachyum against spoilage fungi of 'White Bread' and 'Eba', an indigenous staple food in Southern Nigeria. African Journal of Microbiology Research 4(11):1076-1081.

Jung BO, Kim CH, Choi KS, Lee YM, Kim J (1999). Preparation of amphiphilic chitosan and their antimicrobial activities. Journal of Applied Polymer Science 72:1713-1719.

Lee SS. Robinson FM, Wong HY (1981). Rapid determination of yeast viability. Biotechnology and Bioengineering Symposium 11:641649.

Leech NL, Barrett KC, Morgan GA (2008). SPSS for intermediate statistics: use and interpretation. Lawrence Erlbaum Associates (3rd ed), New York

Liman Z, Selmi S, Sadok S, Elabed A (2010). Extraction and characterization of chitin and chitosan from crustacean byproducts: Biological and physicochemical properties. African Journal of Biotechnology 10(4):640-647.

Marcilla A, Zarzo A, Del Río MA (2006). Effect of storage temperature on the flavour of Citrus fruit. Spanish Journal of Agricultural Research 4(4):336-344.
Martin-Diana AB, Rico D, Barat J, Barry-Ryan C (2009). Orange juices enriched with chitosan: optimisation for extending the shelf-life. Innovative Food Science and Emerging Technologies 10:590-600.

Milne-Redhead E (1952). Marantaceae. In: Turrill WB, MilneRedhead E (Eds). Flora of Tropical East Africa. Crown Agents, London.

Moshi MJ, Innocent E, Magadula JJ, Otieno DF, Weisheit A, Mbabazi PK, Nondo RSO (2010). Brine shrimp of some plants used as traditional medicine in Kagera Region, North West Tanzania. Tanzania Journal of Health Research 12:63-67.

Ojekale AB, Makinde SCO, Osileye O (2007). Phytochemistry and anti-microbial evaluation of Thaumatococcus daniellii Benn. (Benth.) Leaves. Nigerian Food Journal 25(2):176-183.

Onwueme IC, Onochie BE, Sofowora EA (1979). Cultivation of Thaumatococcus danielli-the Sweetner. World Crop 31:321-335.

Perricone M, Arace E, Corbo M, Sinigaglia M, Bevilacqua A (2015). Bioactivity of essential oils: a review on their interaction with food components. Frontiers in Microbiology 6(76):1-7.

Sin HN, Yusof S, Sheikh AHN, and Rahman RA (2006). Optimization of enzymatic clarification of sapodilla juice using response surface methodology. Journal of Food Engineering (73):313-319.

Tiwari BK, Valdramidis VP, Donnell PO, Muthukumarappan KBN, Bourke P, Cullen PJ (2009). Application of natural antimicrobials for food preservation. Journal of Agricultural and Food Chemistry 57:5987-6000. 